\title{
Ocena efektywności modernizacji lokomotywy spalinowej serii SM42 w oparciu o analizę lcc
}

\author{
$W$ artykule przedstawiono ocenę efektywności modernizacji lokomotywy \\ spalinowej serii SM42 w wariancie $6 \mathrm{Dg}$. Ocenę efektywności w porównaniu \\ do niezmodernizowanej lokomotywy dokonano $w$ oparciu o analize kosztu \\ cyklu trwałości (analizę LCC).
}

\section{Wstęp}

Wśród przedsięwzięć zmierzających do podwyższenia efektywności transportu kolejowego istotną rolę spełniają działania w zakresie obniżenia kosztów eksploatacji i utrzymania pojazdów trakcyjnych. Drogą do osiagnięcia tego celu jest modernizacja lokomotyw spalinowych, dodatkowo uwzględniająca uwarunkowania $\mathrm{w}$ zakresie emisji spalin i hałasu. Podstawowe założenia modernizacji lokomotyw to $[1,2]$ :

- poprawa efektywności eksploatacji poprzez zmniejszenie zużycia paliwa i materiałów eksploatacyjnych;

- zwiększenie przebiegów międzynaprawczych;

- dostosowanie parametrów technicznoeksploatacyjnych do wymagań przepisów międzynarodowych;

- poprawa wskaźników oddziaływania na środowisko naturalne;

- poprawa warunków pracy maszynisty lokomotywy;

- wprowadzenie nowoczesnych systemów sterowania.

W ostatnich latach ze strony przewoźników kolejowych obserwuje się duże zainteresowanie modernizacją lokomotyw spalinowych. Zostały wykonane lub są $\mathrm{w}$ trakcie wykonywania modernizacje lokomotyw liniowych serii: ST44, SU45, SU46, SP32 oraz lokomotyw manewrowych: SM48 i SM42.

Przedmiotem niniejszego artykułu jest ocena efektywności modernizacji manewrowej lokomotywy spalinowej serii SM42. Ocena ta została przeprowadzona $\mathrm{w}$ ramach prac badawczych wykonanych $\mathrm{w}$ Instytucie Pojazdów Szynowych Politechniki Krakowskiej w latach 2007 i 2010 [3, 4]. Do wykonania oceny efektywności zastosowano analizę kosztu cyklu trwałości (Life Cycle Cost Analysis) oraz analizę korzyści-kosztów (Cost-Benefit Analysis). Szczegółowy opis zastosowanych metod analitycznych zawarty jest m.in. w pracach $[5,6,7,8]$. Ze względu na ograniczenia dotyczące objętości artykułu, przedstawiono w nim wybrane aspekty dotyczace oceny efektywności modernizacji lokomotywy SM42 uzyskane wyłącznie w ramach analizy kosztu cyklu trwałości.

\section{Warianty podlegające ocenie efektywności}

W ocenie efektywności modernizacji lokomotywy SM42 przyjęto dwa warianty:

1. SM42 a8C22: niezmodernizowana lokomotywa spalinowa serii SM42 z silnikiem HCP a8C22,

2. SM42 CAT C27: zmodernizowana lokomotywa SM42 w wersji 6Dg z silnikiem Caterpillar C27.

\subsection{Zmodernizowana lokomotywa SM42 w wersji $6 \mathrm{Dg}$}

W 2007 roku Spółka Akcyjna NEWAG wykonała dla potrzeb przedsiębiorstwa ISD Huta Częstochowa Sp. z o. o., prototypową modernizację lokomotywy spalinowej serii SM42. Lokomotywa po modernizacji została oznaczona symbolem 6Dg. W 2009 roku podczas TRAKO 2009 została zaprezentowana lokomotywa SM42-1501 zmodernizowana dla PKP Cargo S.A., która oznaczona została symbolem 6Dga (rys. $1)$.

a)

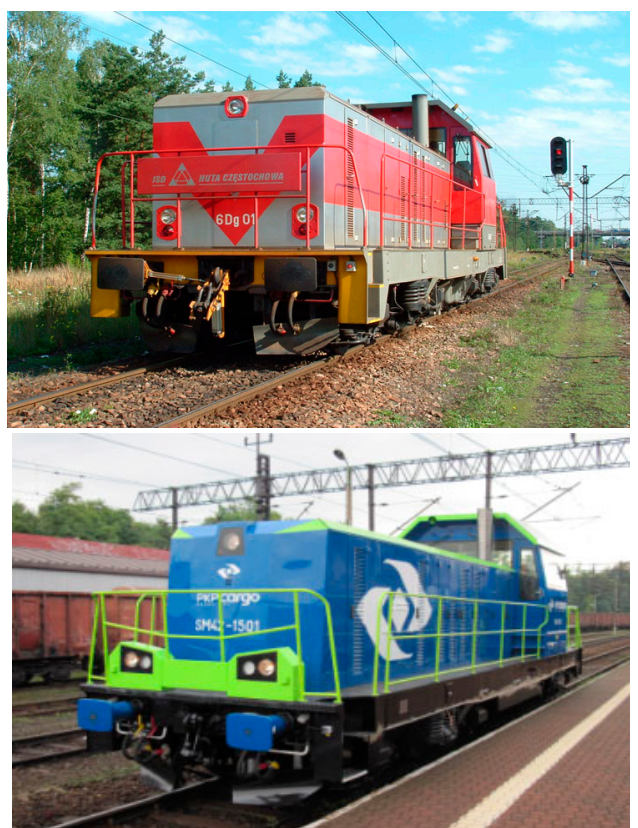

Rys. 1. Zmodernizowana lokomotywa SM42 a) w wersji 6Dg dla ISD Huta Częstochowa, b) w wersji 6Dga dla PKP Cargo (Foto.: Maciej Górowski) 
Dotychczasowy silnik został zastapiony nowym 12-cylindrowym wysokoprężnym silnikiem spalinowym firmy CATERPILLAR model C27 o mocy 652 kW (875 KM). Na lokomotywie zabudowano zespół prądnic synchronicznych, składający się z prądnicy głównej i prądnicy pomocniczej. W obwodach pomocniczych zainstalowano falowniki do regulacji silników elektrycznych AC napędów urządzeń pomocniczych lokomotywy. Zmodernizowana lokomotywa posiada przekładnię elektryczną AC-DC (prąd przemienny-prąd stały) [3, 4].

Układy wspomagające pracę silnika, tj. układ chłodzenia, układ zasilania, układ wydechowy, mikroprocesorowy układ sterowania oraz rozwiązania konstrukcyjne połączenia silnika z prądnicą oraz zabudowy zespołu prądotwórczego na ramie lokomotywy zostały w całości zaprojektowane i wykonane po raz pierwszy w wersji z silnikiem C27. Nowoczesna bryła lokomotywy odpowiada współczesnym wymaganiom ergonomii i bezpieczeństwa. Kabina maszynisty została poddana kompleksowej modernizacji wraz ze zwiększeniem jej powierzchni użytkowej. W kabinie zabudowane zostały dwa ergonomiczne pulpity sterownicze $\mathrm{z}$ fotelami maszynisty. Na pulpicie zamontowano monitor, na którym wyświetlane są parametry pracy lokomotywy, co umożliwia ich stałe monitorowanie. Nowa kabina spełnia warunki ergonomii i wysokiego komfortu pracy $[3,4]$.

W wyniku dokonanej modernizacji powstała pierwsza zarówno na rynku polskim, jak $\mathrm{i}$ europejskim lokomotywa $\mathrm{z}$ silnikiem spalinowym nowej generacji, spełniającym normy emisji spalin, które obowiązują od stycznia 2009 r. Wybrane parametry techniczne lokomotywy zostały zestawione w tabeli 1.

Parametry techniczne lokomotywy spalinowej typu 6Dg (6Dga)

Tabela 1

\begin{tabular}{|c|l|c|}
\hline Lp. & \multicolumn{1}{|c|}{ Parametr } & Wartość \\
\hline 1 & Układ osi & Bo-Bo \\
\hline 2 & Szerokość toru & $1435 \mathrm{~mm}$ \\
\hline 3 & Rodzaj przekładni & Elektryczna AC/DC \\
\hline 4 & Długość ze zderzakami & $14240 \mathrm{~mm}$ \\
\hline 5 & Szerokość & $3170 \mathrm{~mm}$ \\
\hline 6 & Odległość od główki szyny & $4323 \mathrm{~mm}$ \\
\hline 7 & Masa służbowa lokomotywy & $70000 \mathrm{~kg}$ \\
\hline 8 & Pojemność zbiornika paliwa & 23501 \\
\hline 9 & Moc znamionowa & $652 \mathrm{~kW}(875 \mathrm{KM})$ \\
\hline 10 & Prędkość obrotowa & $1800 \mathrm{obr} . / \mathrm{min}$ \\
\hline 11 & Ilość i układ cylindrów & $\mathrm{V} 12$ \\
\hline 12 & Zużycie paliwa na biegu jałowym & $4,5 \mathrm{l} / \mathrm{h}$ \\
\hline 13 & Jednostkowe zużycie paliwa & $200 \mathrm{~g} / \mathrm{kWh}$ \\
\hline 14 & Pojemność silnika spalinowego & 271 \\
\hline 15 & Siła pociagowa przy rozruchu & $219 \mathrm{kN}$ \\
\hline 16 & Prędkość maksymalna & $85 \mathrm{~km} / \mathrm{h}$ \\
\hline
\end{tabular}

Obecnie w czynnej eksploatacji znajduje się siedem zmodernizowanych lokomotyw SM42 w wersji 6Dg (6Dga): 3 szt. w przedsiębiorstwie ISD Huta Częstochowa Sp. z o.o. oraz 4 szt. w PKP Cargo S.A., w Górnośląskim Zakładzie Spółki w Rybniku.

\section{Analiza kosztu cyklu trwałości}

Do oceny efektywności modernizacji lokomotywy SM42 zastosowano analizę kosztu cyklu trwałości (analizę LCC). Analiza została przeprowadzona zgodnie $\mathrm{z}$ zaleceniami międzynarodowej normy: PN-EN 60300-3-3:2006 Zarzadzanie niezawodnościq. Przewodnik zastosowań - Szacowanie Kosztu Cyklu Życia. Jako miarę efektywności przyjęto koszt cyklu trwałości (LCC) obliczony w 25-letnim okresie eksploatacji lokomotywy. Przyjęto założenie, że analiza ma charakter porównawczy, polegający na porównaniu efektów ekonomicznych uzyskiwanych przy eksploatacji lokomotywy SM42 przed modernizacją do efektów uzyskiwanych po jej modernizacji.

\subsection{Założenia wstępne}

$\mathrm{Na}$ podstawie danych eksploatacyjnych niezmodernizowanych lokomotyw SM42 zebranych w latach 2007-2009 u jednego z czołowych przewoźników kolejowych, określono harmonogram obciążenia silnika spalinowego oraz określono następujące wskaźniki będące podstawą do wykonania oceny efektywności modernizacji:

- średni czas pracy silnika spalinowego: 5.000 [mth/rok],

- średni przebieg lokomotywy: 42.000 [km/rok],

- średnie zużycie paliwa: $72.696,0$ [kg/rok],

- średnie zużycie oleju silnikowego: 447,6 [kg/rok] lub $0,62 \%$ zużycia paliwa.

Ponadto dysponowano danymi $\mathrm{z}$ eksploatacji nadzorowanej lokomotyw zmodernizowanych $\mathrm{w}$ wersji 6Dg i 6Dga, co umożliwiło weryfikację zastosowanego modelu kosztu i przeprowadzonej analizy.

\subsection{Model kosztu LCC}

Dla analizowanych wariantów opracowano wspólny model kosztu, w którym LCC wyrażono następującą formułą:

gdzie:

$$
L C C=K N+K P
$$

$K N-$ koszty nabycia,

$K P$ - koszty posiadania.

Koszty nabycia $(\mathrm{KN})$ w wariancie bazowym (wariant SM42 a8C22) stanowią koszty naprawy głównej. Dla zmodernizowanej lokomotywy SM42 (wariant SM42 CAT C27) koszty nabycia stanowią łączne wydatki na modernizację, uwzględniające m.in.: koszty dokumentacji, koszty dopuszczenia UTK, koszty zakupu i dostawy silnika spalinowego, koszty niezbędnych podzespołów i elementów oraz koszty robocizny. Założono, że modernizacja lokomotywy SM42 będzie przeprowadzona $w$ ramach naprawy głównej pojazdu. Koszty posiadania (KP) to koszty związane z eksploatacją lokomotywy, czyli utrzymaniem i użytkowaniem. 
Jednym $\mathrm{z}$ najważniejszych etapów w tworzeniu modelu LCC jest definicja struktury kosztu, polegająca na dekompozycji kategorii kosztów na najwyższym poziomie, które wynikają z przyjętej formuły na LCC, na koszty składowe. Każda kategoria kosztu powinna zostać podzielona aż do osiagnięcia najniższego poziomu tzw. elementu kosztu. Element kosztu jest to taka wartość, której nie można wyrazić jako sumę innych kosztów. Jest on definiowany za pomocą matematycznych formuł zawierających parametry, wartości stałe lub funkcje. Takie podejście ma tę zaletę, że jest usystematyzowane i uporządkowane, a zatem dające wysoki poziom ufności, że wszystkie elementy kosztu mające duże znaczenie w LCC zostały uwzględnione. Koncepcję definiowania elementów kosztu w modelu LCC można znaleźć np.: w jednym z programów Ministerstwa Obrony USA Integrated Logistics Support (Dyrektywa DOD 4100.35 z 1968 r.) oraz w normie PN-EN 60300-3-3 z 2006 roku. Strukturę kosztów, która została przyjęta w modelu LCC przedsta-wiono na rysunku 2.

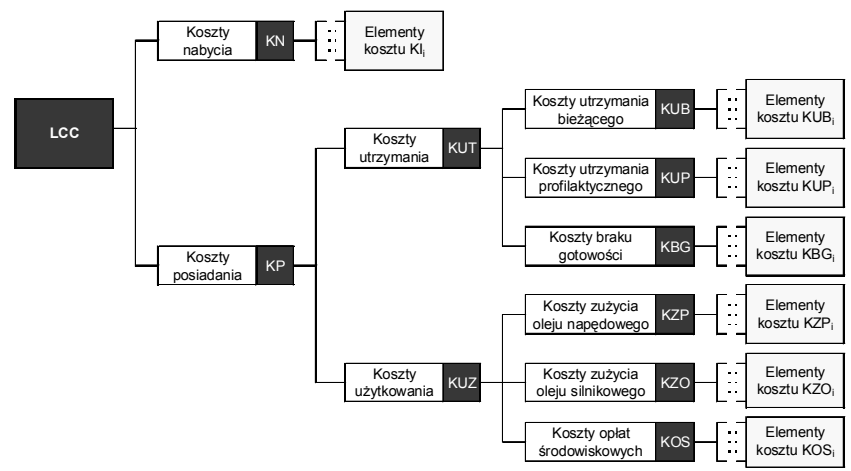

Rys. 2. Struktura kosztów dla analizowanych wariantów modernizacji

W zastosowanym modelu LCC zdefiniowano 10 elementów kosztów wykorzystując 26 parametrów i funkcji. Kalkulację LCC oparto na niezdyskontowanych wartościach kosztów, a ich wycenę oparto o ceny stałe (netto) z poziomu 2009 roku. Jednym z elementów kosztu w zastosowanym modelu były koszty utrzymania bieżącego (KUB) związane z naprawami bieżącymi lokomotywy. KUB uwzględniają zarówno koszty robocizny jak również koszty materiałów i części zamiennych. Do wyznaczenia KUB wykorzystano funkcję odnowy $\mathrm{H}(\mathrm{t})$ wyznaczoną w ramach analizy niezawodnościowej. Koszty utrzymania bieżącego lokomotywy w analizowanych wariantach wyrażono następującą formułą:

$$
K U B=\left[H\left(t_{i}\right)-H\left(t_{i-1}\right)\right] \cdot[(M M H \cdot C P H)+A C M][\mathrm{zl} / \mathrm{rok}]
$$

$$
\text { gdzie: }
$$

$H\left(t_{i}\right)$ - wartość funkcji odnowy w i-tym roku eksploatacji,

$M M H$ - średnia pracochłonność naprawy bieżącej,
$C P H-$ koszt roboczogodziny przy naprawie bieżącej,
$A C M$ - średni koszt zużycia materiałów w naprawie bieżącej.

Koszty utrzymania profilaktycznego (KUP) stanowią wydatki na naprawy i przeglądy okresowe wynikające z cyklu utrzymania lokomotywy.

Koszty braku gotowości (KBG) to suma kosztów będących konsekwencją znajdowania się lokomotywy w stanie uniemożliwiającym wykonanie przewidzianych do realizacji zadań. Do kosztów braku gotowości zalicza się np.: koszty kar umownych, koszty gwarancji, koszty utraconych możliwości i inne. W definicji KBG wykorzystywany jest wskaźnik gotowości technicznej wyznaczony $w$ ramach analizy niezawodnościowej.

Koszty zużycia oleju napędowego (KZP) i oleju silnikowego (KZO) obliczono na podstawie:

- charakterystyk uniwersalnych silników HCP a8C22 i CAT C27,

- danych eksploatacyjnych zgromadzonych przez PKP Cargo S.A. dotyczących niezmodernizowanej i zmodernizowanej lokomotywy SM42,

- danych eksploatacyjnych zgromadzonych przez ISD Huta Częstochowa Sp. z o. o. dotyczących zmodernizowanej lokomotywy SM42.

Koszty opłat środowiskowych (KOS) związane są z opłatami ustalonymi przez Ministerstwo Środowiska za emisję szkodliwych składników zawartych w spalinach. Wysokość kosztów opłat środowiskowych zależy od wskaźników publikowanych przez Ministerstwo i zużycia paliwa przez lokomotywę.

\subsection{Analiza modelu kosztu}

Analiza modelu kosztu wykazała, że proponowany wariant modernizacji lokomotywy SM42 w wersji 6Dg (6Dga) jest w pełni uzasadniony ekonomicznie. Z obliczeń przeprowadzonych przy zastosowaniu oprogramowania CATLOC wynika, że modernizacja lokomotywy zapewnia bardzo wysokie oszczędności w kosztach całkowitych - około 6,0 mln zł, tj. 37,2\% mniej w porównaniu do lokomotywy niezmodernizowanej.

Porównanie kosztów całkowitych (LCC) dla analizowanych wariantów w 25-letnim okresie eksploatacji przedstawiono na rysunku 3.

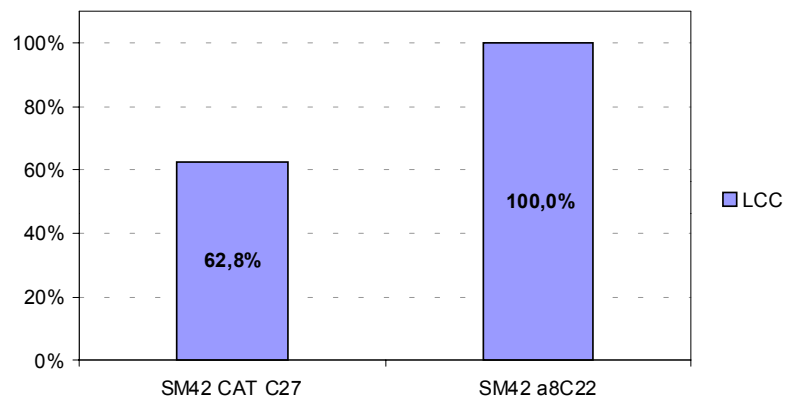

Rys. 3. Porównanie LCC dla analizowanych wariantów modernizacji 
Dla niezmodernizowanej lokomotywy SM42 kosztami dominującymi są koszty zużycia paliwa (KZP) $34,8 \%$ oraz koszty utrzymania profilaktycznego $37,5 \%$. Koszty napraw bieżących oraz braku gotowości stanowią 16,8\% kosztów całkowitych (rys. 4).

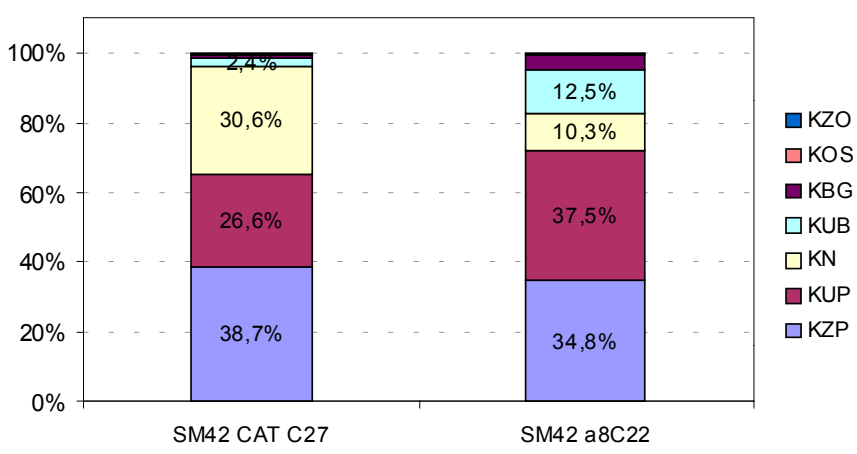

Rys. 4. Koszty dominujące w LCC analizowanych wariantów modernizacji lokomotywy SM42.

KZP - koszty zużycia paliwa, KUP - koszty utrzymania profilaktycznego, KN - koszty nabycia, KUB - koszty utrzymania bieżącego, KBG - koszty braku gotowości, KOS - koszty opłat środowiskowych, KZO - koszty zużycia oleju silnikowego

Dla zmodernizowanej lokomotywy SM42 w wersji 6Dg koszty nabycia (KN) związane z nakładami poniesionymi na modernizację stanowią 30,6\% kosztów całkowitych. Największe oszczędności w ujęciu wartościowym w stosunku do lokomotywy niezmodernizowanej dotyczą kosztów zużycia oleju napędowego oszczędności rzędu 30,2\% i oleju silnikowego około $57,8 \%$. Biorąc pod uwagę aktualną tendencję wzrostu cen paliw, w planowaniu długookresowym ma to ogromne znaczenie. Największy udział w LCC mają koszty zużycia paliwa (KZP) - 38,7\%. Znaczące obniżenie kosztów generowanych w cyklu trwałości lokomotywy zmodernizowanej, otrzymano dzięki zwiększeniu niezawodności, gotowości i dostępności części zamiennych. Przekłada się to na redukcję nakładów na utrzymanie bieżące oraz niższe koszty obsług profilaktycznych pojazdu (przeglądy, naprawy okresowe). Koszty utrzymania profilaktycznego (KUP) lokomotywy zmodernizowanej stanowią około $26,6 \%$ kosztów ogółem, a utrzymania bieżącego (KUB) niewiele ponad 2,4\%.

Na rysunku 5 przedstawiono rozkład kosztów posiadania dla zmodernizowanej lokomotywy SM42 w 25-letnim okresie eksploatacji, gdzie: KZP - koszty zużycia paliwa, PU5 - koszty poziomu utrzymania 5, PU4 - koszty poziomu utrzymania 4, PU3 - koszty poziomu utrzymania 3 , PU2 - koszty poziomu utrzymania 2, PU1 - koszty poziomu utrzymania $1, \mathrm{KUB}$ koszty napraw bieżących, KBG - koszty braku gotowości, KOS - koszty opłat środowiskowych, KZO koszty zużycia oleju silnikowego.

W przeprowadzonej analizie wykazano, że modernizacja lokomotywy spalinowej serii SM42 w wersji 6Dg zapewnia znacząco istotne oszczędności w kosztach eksploatacji w stosunku do lokomotywy niezmo-

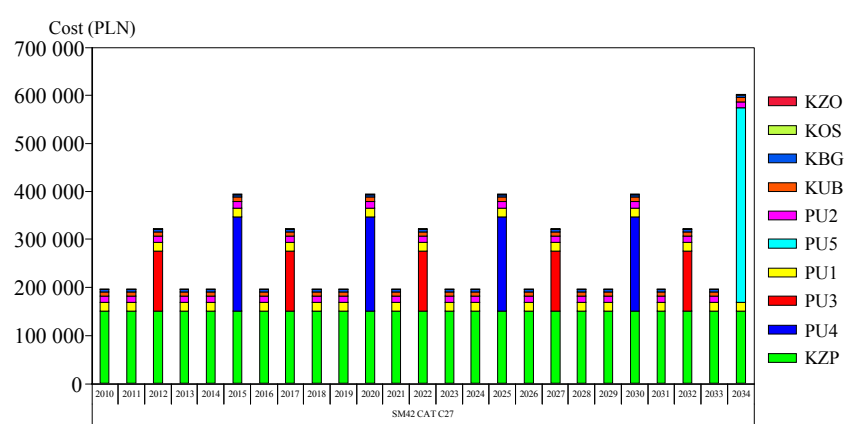

Rys. 5. Rozkład kosztów posiadania dla zmodernizowanej lokomotywy SM42 w 25-letnim okresie eksploatacji

dernizowanej. W tabeli 2 zestawiono poziom oszczędności dla wybranych kategorii kosztów uzyskiwany w ciagu jednego roku eksploatacji lokomotywy zmodernizowanej.

\section{Podsumowanie}

Celem modernizacji lokomotywy spalinowej serii SM42 jest przywrócenie, poprawa i dostosowanie do współczesnych wymagań własności użytkowych. Główne obszary przebudowy i modernizacji powinny dotyczyć: zespołu napędowego z silnikiem o ograniczonym poziomie emisji spalin, sterowania mikroprocesorowego zespołem silnik - prądnice, poprawy ergonomii kabiny i stanowiska pracy operatora (maszynisty), ekonomicznego napędu maszyn i urządzeń pomocniczych oraz poprawy elementów układu hamulcowego.

Baza danych wyjściowych do analizy i oceny efektywności modernizacji została oparta na aktualnych kosztach utrzymania profilaktycznego i bieżącego oraz cenach oleju napędowego i silnikowego. Dane dotyczące poziomu zużycia paliwa zostały wykorzystane w stanie rzeczywistym i uwzględniały zróżnicowany charakter pracy lokomotywy: od lekkiej pracy manewrowej ze składami pasażerskimi do ciężkiej pracy na górce rozrządowej ze składami towarowymi. W przeprowadzonej ocenie efektywności wykazano, że modernizacja lokomotywy spalinowej serii SM42 $\mathrm{w}$ wersji 6Dg (6Dga) zapewnia znacząco istotne oszczędności w kosztach eksploatacji w stosunku do pojazdu niezmodernizowanego. W okresie 25 lat użytkowania pojazdu oszczędności te mogą wynosić około 6,0 mln zł dla jednej lokomotywy.

\section{Literatura}

[1] Marciniak Z., Dotychczasowe projekty modernizacji lokomotyw spalinowych w Polsce, Technika Transportu Szynowego, 9/2005.

[2] Tutecki A., Modele decyzyjne w odnowie parku spalinowych pojazdów trakcyjnych, Technika Transportu Szynowego, 9/2005.

[3] Studium techniczno-ekonomiczne odnowy parku pojazdów trakcyjnych eksploatowanych przez PKP Cargo S.A. Etap IV Modernizacja manewrowej lokomotywy spalinowej serii SM42, Projekt badawczy, Politechnika Krakowska, Instytut Pojazdów Szynowych, Kraków, 2007. 
Poziom oszczędności w ujęciu rocznym dla zmodernizowanej lokomotywy SM42 w wersji 6Dg w stosunku do lokomotywy niezmodernizowanej [4]

Tabela 2

\begin{tabular}{|c|c|c|c|c|c|c|}
\hline $\begin{array}{c}\text { Kategoria } \\
\text { kosztu }\end{array}$ & $\begin{array}{c}\text { Koszty } \\
\text { utrzymania } \\
\text { profilak- } \\
\text { tycznego } \\
\text { KUP }\end{array}$ & $\begin{array}{c}\text { Koszty } \\
\text { utrzymania } \\
\text { bieżącego } \\
\text { KUB }\end{array}$ & $\begin{array}{c}\text { Koszty } \\
\text { zużycia } \\
\text { oleju nape-- } \\
\text { dowego } \\
\text { KZP }\end{array}$ & $\begin{array}{c}\text { Koszty } \\
\text { zużycia } \\
\text { oleju silni- } \\
\text { kowego } \\
\text { KZO }\end{array}$ & $\begin{array}{c}\text { Koszty } \\
\text { braku } \\
\text { gotowości } \\
\text { KBG }\end{array}$ & $\begin{array}{c}\text { Koszty } \\
\text { opłat } \\
\text { środowisk. } \\
\text { KOS }\end{array}$ \\
\hline $\begin{array}{c}\text { Poziom } \\
\text { oszczędności }\end{array}$ & $144.786,7 \mathrm{zl}$ & $68.208,7 \mathrm{zl}$ & $65.424,0 \mathrm{zl}$ & $981,2 \mathrm{zl}$ & $\begin{array}{c}22.869,4 \\
\mathrm{zl}\end{array}$ & $494,2 \mathrm{zł}$ \\
\cline { 2 - 7 } & $53,6 \%$ & $87,7 \%$ & $30,2 \%$ & $57,8 \%$ & $83,8 \%$ & $30,2 \%$ \\
\hline
\end{tabular}

[4] Ocena efektywności modernizacji lokomotywy serii SM42 w oparciu o bieżace dane eksploatacyjne, Projekt badawczy, Politechnika Krakowska, Instytut Pojazdów Szynowych, Kraków 2010.

[5] Szkoda M., Metoda oceny kosztu cyklu trwałości (LCC) pojazdu szynowego. Konferencja SITK: Wymagania $w$ zakresie ochrony środowiska dla taboru kolejowego. Kierunki modernizacji i rozwoju konstrukcji, Cedzyna 2006.
[6] Szkoda M., Analiza kosztu cyklu trwałości LCC w ocenie pojazdów szynowych. Seminarium SITK: Rynek lokomotyw - rozwiazania techniczne. Aspekty prawne i ekonomiczne modernizacji lokomotyw, Dobieszków 2006.

[7] Tulecki A., Szkoda M., Koszt cyklu trwałości LCC jako model decyzyjny modernizacji pojazdów szynowych, XVII Konferencja Naukowa POJAZDY SZYNOWE. Kazimierz Dolny, 2006.

[8] Hawranek P.M., Behrens W., Poradnik przygotowania przemystowych studiów feasibility, UNIDO, Warszawa 1993. 